\title{
The Lens of 2 Samuel 17:1-23 in Managing Suicide in Nigeria
}

\author{
Favour C. Uroko \& Solomon Enobong \\ http://dx.doi.org/10.4314/ujah.v22i2.9
}

\section{Abstract}

Although progress has been made in examining different aspects of suicide in Nigeria, literature has yet to adequately explore suicide from the Old Testament lens. In this study, we extended literature by examining 2 Samuel 17:1-23 and its relevance to the increasing suicide rate among Nigerians. In the pericope, Ahithophel committed suicide by hanging himself due to the physical, mental, and emotional challenges he found himself. All these challenges culminate in frustration. These reasons also seem to be factors that have sustained the suicide rate in Nigeria. The frustrated in Nigeria are in a desperate state of mind. They are prone to adopting wild and hasty strategies to address their challenges, which is taking their lives knowingly. Findings reveal that the motivating factors to the increasing state of suicide in Nigeria are frustration, poverty, family challenges, ego, emptiness, and traumatic events. People find it difficult to feed, find job, bear children, and endure intimidation and harassment, among others. People think that the shortest way of mitigating these anomalies is to kill oneself. The impacts include the fact that people bereaved by suicide committed by their relatives are also at an increased risk of suicide, depression, and psychiatric admission. Suicide leaves the family of the victim in poverty, especially if the person is the breadwinner of the family. It also makes the family of the person that committed suicide to feel isolated. The import of Ahithophel resort to suicide is believed to speak anew to the increasing suicide rates among Nigerians. The narrative analysis method was adopted in this study. As part of the recommendations, Ahithophel committed suicide because things he expected to work out for him failed to. In the same vein, Nigerians should not expect things to always work well for them. 
Also, there is also a need for faith-based collaborations in sensitizing youths on the dangers of committing suicide.

\section{Keywords: Old Testament, Ahithophel, Frustration, Suicide, 2 Samuel 17, Nigeria}

\section{Introduction}

Frustrated people who are in a desperate state are prone to adopting wild and hasty strategies to address their problems and challenges. Challenges such as depression, frustration, financial trouble, or even spiritual problems are the prime movers of actions with fatal consequences. People suffering from physical, mental, and emotional challenges usually find ways of resolving these crises. Consider, for example, on 7 December 2021, a man by name Adegbite hung himself on his seeking fan after losing 150,000 to betting. The money was given to him by his boss to pay his colleagues, which he hoped to replace it after winning more money (Odenyi, 2021). Also, a final year student, Samuel Elias, of the Department of Religion and Cultural Studies, University of Nigeria, Nsukka, who committed suicide due to his failure to graduate with the classmates (Mac-Leva, Ibrahim \& Usman 2019); or a policeman in Ondo State who shot himself after discovering his wife was promiscuous (Dayo 2020).

There is increasing frustration in Nigeria. This is seen in high poverty level, increasing unemployment, marital instability, family pressures and expectations, disappointment, and the feeling of being a failure in life. Furthermore, the way that youth people abused substances makes them easy prey to suicidal thoughts and actions. Most reports on suicide in Nigeria shows that chemicals 
such as sniper, self-cutting and setting oneself on fire, hanging oneself and use of knife or gun on oneself are the commonest methods of suicidal behaviour. Nigerians who committed suicide had lofty dreams about life and looked into the future with great expectations. They never thought life could defeat them, so they worked hard and hoped they would win all life's battles. They loved and were loved by others in return and life was indeed good and joyful. But soon, their dreams began to fade and depression crawled in; hope gave way to despair while sadness took the place of joy in their hearts. Then came the chiming of death; they raced unto it and that was the end of it all (Agbedo, 2019). There are several passages of frustration in the Old Testament, but 2 Samuel 17 presents a succinct narrative of a frustrated man who took his life by hanging.

2 Samuel 17:1-23 present a similar case of a frustrated man, Ahithophel, who adopted a wild and hasty strategy in response to the predicament he found himself (Fokkelman 1981; Bodner 2002). 2 Samuel 17 comes as the climax of Ahithophel frustrations. Ahithophel was Absalom counsellor. He deemed his advice infallible. Ahithophel thought his decisions and advice would be accepted by Absalom (as it has always been), but he felt humiliated and frustrated following Absalom's refusal. He decided to commit suicide in his house. Narratives such as 2 Samuel 17:1-23 is recognized "for 'showing' rather 'telling' their readers what to do" (Long 1993:165-181). In narrative discourse, the character actions, words, and feelings contribute to the events of the story - they are the driving force. The narrative analysis method was adopted in this study. This method is important because deriving ethical formulation from 2 Samuel 17:1-23 requires paying due attention to the activities of the characters such as Ahithophel and the 
situation he found himself. This makes the narrative a semiotic mechanism of alternate universes (Margolin 1990:455).

Although progress has been made in examining different aspects of suicide in Nigeria, literature is yet to adequately explore suicide from the Old Testament lens. In this study, we extended literature by examining 2 Samuel 17:1-23 and its import to the increasing suicide rate among Nigerians. In the pericope, Ahithophel committed suicide by hanging himself due to the physical, mental, and emotional challenges he found himself. All these challenges culminate to frustration. This essay first surveys the historical and literary text of the 2 Samuel 17:1-23; a close reading of the context reveals the prime propellants of the decision of Ahithophel to take his life. Second, this article examines the lifethreatening situations faced by Nigerians which have necessitated the rise cases of suicide in Nigeria. Third, 2 Samuel 17:1-23 was as limelight in tackling the increasing suicide rates among Nigerians.

\section{The Historical and Literary Context of 2 Samuel 17:1-23}

Context is the key to any research. It helps to understand the thesis of any research. The books of Samuel cover the period from the last days of the temple of Shiloh until near the end of David's reign (1050-970B.C) (Gordon 1998:21). At this time, the Hittite and Babylonian kingdoms were in decline. Hertzberg (1965:17) writes that the "Books of Samuel contain that part of the history of Israel which describes the foundation of the State, running from the close of the period of the Judges to the establishment of the united kingdom". 
The conflict in 2 Samuel begins with Absalom's challenge to his father's sovereignty (2 Sam 13-19), Absalom's exile and reconciliation (2 Sam 14); Absalom's attempt at succession (2 Sam 15); David's abandonment of Jerusalem and the ark (2 Sam 15:1316:14) and the relegation of the significance of Ahithophel in Absalom's circle of friends (2 Sam 16:15-17:23). Ahithophel is the major character in the narrative. . The relegation of Ahithophel led to his decision to take his life. Hastings, Selbie, Lambert \& Matthews (1930:18) sketched that Ahithophel was disgusted at the collapse of his influence and hanged himself. Ahithophel's suicide is also portrayed as a premeditated act of despair, due to the touch to convince which he lost (Campbell \& Flanagan 2018:158). Desmond \& Rosner (2000:179) say that from a biblical-theological point of view a key aspect of 2 Samuel is how the earlier promises given to the patriarchs and Israel are partially fulfiled in the reign of David - violence within his house and the civil war that let so increased suicides in Israel.

2 Samuel 17 has the setting in Jerusalem and Ahithophel was from the town of Giloh (Joshua 15:51-55). He was of the tribe of Caleb. Ahithophel was known for his knowledge, wisdom and understanding (I Chronicles 27:33). Ahithophel served David in Hebron before he turned against David, joins the conspiracy of Absalom. He was betrayed and he allowed bitterness entered his sense of reasoning. Other characters in this chapter included Absalom, Hushai, Zadok, Abiathar, Jonathan and Ahimaaz, Enrogel, David, Shobi, Barzillai and David were minor characters. From Chapter 16 of second Samuel, David was running away from the presence of Absalom his son. David was at Ziba (2 Sam 16:2) when he was abused by Shimmei that it was because of his sins God used Absalom to be chasing him around. Abishai wanted to kill Shimmei for mocking David, but David restricted him claiming 
"because the LORD hath said unto him, Curse David" (2 Sam 16:10). Shimmei and other enemies could not stop David from triumph, even though the Arameans and Syrians began to move into the north in large numbers (Heater 1991:115).

Ahithophel was on the part of those with Absalom, pursuing David to take his life. In the 'biblical narrative of 2 Samuel 15-17, Absalom conspires against King David, and attempts to seize the throne of Israel. Absalom's rebellion gains a key ally when Ahithophel, designated as one of David's senior advisors, joins the forces of Absalom' (Bodner 2002:63). Ahithophel had always met no resistance with respect to his wills and injunctions been accepted by Absalom. One of his advice was for Absalom to defile his father David concubine in the presence of everybody (2 Sam 16:20-21). Absalom as before choose to obey this advice; he spread a tent upon the top of the house and went into his father's concubines in the sight of all the Israel (2 Sam 16:22). But, by going to his father's harem, Absalom was publicly declaring his claim to the throne, which he had already taken (Tsevat 1958). Hertzberg (1965) recalled that David is reported to have acted similarly with Saul's harem, thus, Ahithophel recommendation to Absalom to take possession of David's harem. Other instances of this practice are found in 2 Sam 12:8 and 1 Kings 2:22-3. Ahithophel saw in such action a decisive breaking of relations between son and father and therefore an opportunity to consolidate support from the antiDavidic camp (Barton \& Muddiman 2002). Unfortunately for him, things worked against his plans, purpose and dreams. 


\section{Understanding 2 Samuel 17:1-23}

The structure reveals that the actions began in v.1 with preliminary incidents from vv.1-4. However, as a general rule with narrative plot, there was an occasioning incident that began in v. 5, this was the beginning of conflict generated up till v.14 where the conflict was intense and began to unravel in v.22. This conflict was finally resolved in v. 23, where the outcome was the death of Ahithophel. This ends the suicide action in the pericope. From vv.1-4, Ahithophel was a major character. His decisions were affirmed and obeyed by his superiors. He was happy that things were working out positively in his favour. He advised Absalom to choose 12,000 men and pursue after David. Ahithophel promised to bring the head of David to Absalom. This advice as with previous pieces of advice from Ahithophel looked promising in the sight of Absalom and the elders of Israel. Ahithophel was pivotal in the story of Absalom (McCarter 1984). This part could be termed "When situations worked out in Ahithophel favour".

However, conflict was generated from v.5. Not as before where Ahithophel words were accepted; this time around, Hushai was called upon by Absalom to examine this advice given by Ahithophel. The conflict became intense in v. 7, when Hushai told Absalom to abandon his usual stance of granting the request of Ahithophel. Ahithophel's counsels Absalom to seize David's before he can gather a formidable army (vv. 1-4), but the Lord defeats it through Hushai (vv. 5-14) (Gray 1999:367). The conflict was eventually unravelled when Absalom and the men of Israel decided to abandon the Ahithophel and his advice and accepted Hushai's admonition (v. 14). Hushai's speech is a masterpiece of oriental eloquence with a clear aim (Hertzberg 1965). From v.15, Ahithophel knew that he had been frustrated from achieving his purpose of seeing David dead. Instead, David was alive and in v.22, 
the same David crossed over to Jordan with all his troops. This structure could be termed "When situations worked against Ahithophel".

The outcome of the conflict could be seen in v. 23 . Ahithophel resolved the conflict by committing suicide. He could not stand the shame of being sidelined from the decision-making process of the warriors of Absalom. For him, the future was shattered, which makes living not necessary. He hanged himself in his house, and no one could save him; he died. This section could be called "Ahithophel resolved to take his life".

\section{When Situations Worked out in Ahithophel's Favour (vv. 1-4)}

Ahithophel said to Absalom, that 'this night' (הָרְיְלָה) he should be

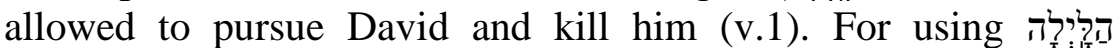
Ahithophel understood that it is a do or die affair for the night. In the morning would be late for his set goals. To kill David was his

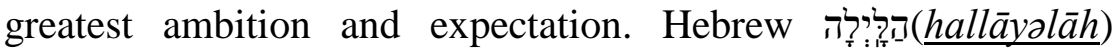
means 'this night', tonight, overnight, indicated that he intended to end David's life which must be an absolute decision endorsed by Absalom, his superior. The first advice of Ahithophel to Absalom was approved and witnessed a humiliation of David's personality and broke any bound that held both Absalom and David. This second advice Ahitophel gave was to completely destroy any bond left (Chafin 2004). The advantages of Ahithophel's plan were that action would be swift and successful and the loss of life minimal; his aim was to kill David alone and return all other fugitives to Jerusalem (Barton and Muddiman 2002). His plan was to spare the followers of David. A close reading further reveals that Ahithophel uses "I" pronoun three times (vv.1-2). Kohlenberger (1987:3301) 


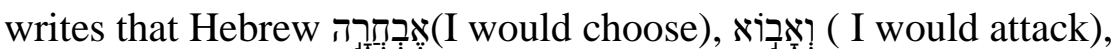
וְהּכּיתתי (I would strike him) were used to show how Ahithophel made the challenge personal and with confidence. He never thought he would fail because his strategy was sensible from a military point of view.

In v. 3, to show how important this mission was to Ahithophel, he tried to persuade the king by telling him that if he is allowed to carry out his mission he would be as if all returned (כָל

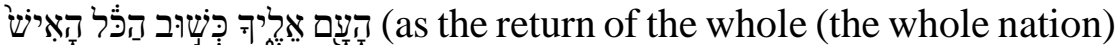
is the man, v.3). He made this statement to show that Ahithophel was desperate and tries to provide reasons why his decision should be consented to. For Ahithophel, David death was his greatest ambition. For Ahithophel, the death of David would bring (šăloww , v.3) [completeness, soundness, welfare, peace]) to him. He used שָׁל adverbially and indirectly, which meant that the peace he sought was himself, and if he losses that peace, there was no

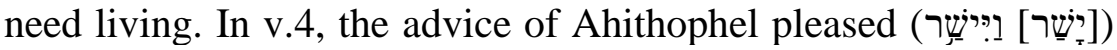
all Israel. All was working well for Ahithophel. In v.4, although this advice from Ahithophel pleased Absalom and the elders of Israel who were present, but Hushai was sent for-for his opinion to be heard (v.5). Hushai, now known as David's friend, came to Absalom in Jerusalem, and with the standard acclamation, 'Long live the king', recognized his authority as king and declared his allegiance to him (v. 16) (Barton \& Muddiman 2002).

\section{When situations worked against Ahithophel's favour (vv. 5-22)}

In v. 5, Hushai idea was sought for. In v.6, Hushai said that

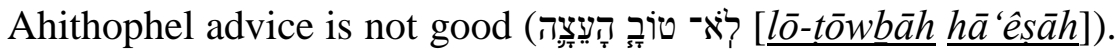
Ahithophel has suggested that he lead the expedition against David, while Hushai considers it important to stress that Absalom must be 
there in person. This was a way of showing discontent and lack of trust in Ahithophel's a priori advice (Hertzberg 1965:351). As a follow-up, Hushai made a long and colourful speech. He also made full use of his persuasive powers (vv. 8-13). First, he sought to discourage Absalom from precipitate action by reminding him of David's military prowess and secondly, by suggesting that Absalom muster all Israel from Dan to Beersheba' to battle, he was appealing to any illusions of grandeur that he may have held (Barton \& Muddiman 2002). This was different from that of Ahithophel who suggested that: He should be allowed to lead the troops and also to kill only David. Hushai instead insisted that Absalom lead the military assault team to kill not only David but all the men with him). Hushai's eloquence and reasoning impressed Absalom and his advisers.

Ahithophel's advice was acknowledged by Absalom as a good one, but he accepted Hushai's advice because Hushai told him, if he fails his supporters would be demoralized (vv. 8b-10) (Akanni \& Weanzana 2006:400). In v. 14, the counsel of Ahithophel was rejected and that of Hushai was accepted. Hushai's advice was considered by Absalom and the elders of Israel as (better, good, efficient, trusted) than that of Ahithophel. Hebrew

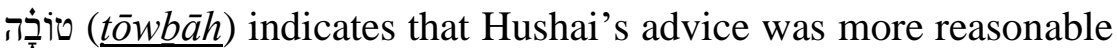
and responsible than the one from Ahithophel. Chaffin (2004) relates that Absalom had compromised his best weapon, the counsel of Ahithophel. Ahithophel's counsel was sincere compared to that of Hushai's, which had a negative intent. This was a big setback for Ahithophel at a time when he thought his breakthrough had come. In v. 22, the advice of Hushai failed; David escaped over to Jordan with his men. 


\section{Ahithophel resolved to take his life (v.23)}

All this while, Ahithophel was observing to see if his ambitions may come through. However, he discovered that he had failed to achieve his aim. Hebrew רָ רָ raah[see, appears, became aware, became visible, displayed, seen]) was used to show that Ahithophel became aware that there was no hope for him; that his plans were visible to have failed; also that his failure was seen by all. Ahithophel rode his ass and went to his house when he saw that his

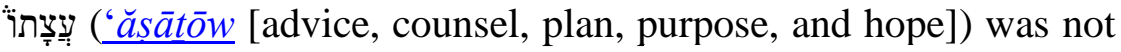

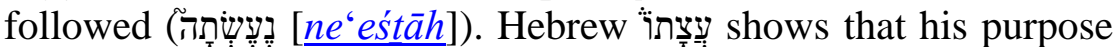

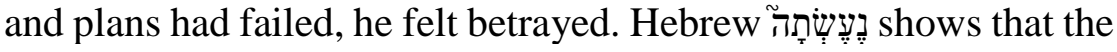
plans and purpose were not followed, accomplished, and yielded fruit; he took a hasty and wild decision, and employed the reckless strategy of first putting his house in order (I:

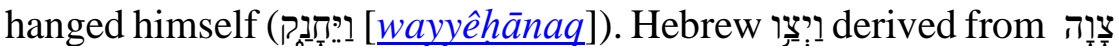
(to lay charge, commissioned) shows that Ahithophel concluded that he had decided to lay the charge of his failure on himself. It also indicates that he had commissioned himself to take his life, due to the frustrated plans. Furthermore, חָנִּק (strangle, killed, hang self) signifies that Ahithiphel committed suicide by hanging himself with a rope which choked him to death. First, the spurned Ahithophel committed suicide (v.23); although the narrative suggests that he took this decision because of wounded pride. It has been suggested that it was more from fear of cruel death at the hands of David (Hertzberg 1964). He thought David would come for a revenge after the conflict had been resolved.This was David's prayer fulfilled in 2 Samuel 15:31(Keil \& Delitzsch 2014).

This close reading reveals that Ahithophel had made successes in his previous influence upon the elites of Israel. In fact, 
2 Sam 16:23 mentions that the counsel of Ahithophel was as if a man has enquired/inquired at the Oracle of God. This shows the extent of Ahithophel's influence on both David and Ahithophel. However, Ahithophel made a wild error of judgment; he decided to resolve the conflict in his life by destroying himself knowingly.

\section{Suicide in Nigeria}

Suicide can be defined as a situation where someone willingly and knowingly takes his life. Stengel sees suicide as self-killing caused by 'personal unhappiness and the belief that one's fellowman is powerless to remedy his condition' (Stengel 1964:1). Normally, the following factors raise a person's risk of suicide: feelings of hopelessness and current losses (Plutchik, Praag, Conte \& Picard 1989:296), depression (Scherr \& Reinemann 2011:264), Posttraumatic stress disorder (Zivin 2007:2193) and poverty (Lemmi et al., 2016:774). Suicide is a conflict resolution strategy to physical, mental, spiritual and emotional suffering. In Nigeria, people commit suicide through various methods. Some hang themselves with a rope to the ceiling fan, set themselves on fire, drink rat poison, and also take insecticide, especially sniper.

\section{Causes of Suicide in Nigeria}

There are various causes of suicide in Nigeria, including frustration, poverty, family challenges, ego, emptiness, and traumatic events.

Frustration is an emotional response to the things an individual never intends to happen to him. Emotion is often produced by frustration. Child and Waterhouse (1953:127) define frustration as 
the event of prevention of a person's progress toward his goal. So many things frustrate the ordinary Nigerian. Some people finished school and have no job to do. Others are in school and have been failing exams notwithstanding their efforts. Others get frustrated when the person they love leaves them for another. Thus, when some Nigerians get frustrated in one activity, it lowers the quality of satisfaction with other activities.

Poverty is a situation where an individual finds it difficult to meet personal and collective needs. In Nigeria, so many people are passing through 'extreme' poverty. This poverty is experienced in health, education and more in living standard. According to the Nigerian Bureau of Statistics, the number of Nigerians that are poor have been estimated to be 82.9 million people and also on average, 4 out of 10 individuals in Nigeria has real per capita expenditures below N137,430 per year, which translates to N376.5 per day (Adesoji 2020). Some do not have money to eat, pay house rent, settle the children's school fees, and marry. Also, some Nigerians are tired of living a life of want and feel bad belonging to the lower class. Thus, they see poverty as an escape mechanism from these challenges, which they know they cannot meet.

Family challenges have also forced Nigerians into committing suicide. Some men commit suicide when they catch their wife in adultery. Others commit suicide when they cannot meet up with their family needs and pressures. Others commit suicide due to domestic violence, mostly committed by females in Nigeria (Adewuya \& Oladipo 2019:1). Girls and adult women are prone to domestic violence in Nigeria. The socioeconomic status of the family may also serve as a factor that leads to suicide in Nigeria.

Ego is also a causative factor to the increasing suicide rate in Nigeria. Some people feel that instead of them passing through 
shame and losing their prestige, they better take their life. Nigerians go as far as living in houses which they cannot pay the rent. So, when the landlord disturbs them, they commit suicide rather than living in a house that does not befit the status they have set in the eyes of the people. Also, people who got relieved of their job, feel ashamed living a life that does not befit their status. They see suicide as the only way to retain their self-esteem.

Emptiness results when one cannot find somebody to confide in. They feel solace and die with no one to share their challenges with. Muanya, Akpunonu and Onyenucheya (2019) corroborate that a sense of isolation is strongly associated with suicidal behaviour. When people cannot find anyone to help them share their ideas and pains, they tend to take solace in committing suicide.

A traumatic event is an incident that may cause mental, physical, emotional, or spiritual harm. Trauma affects that a person's mental and emotional stability. Some Nigerians have taken their lives due to certain shocks that they cannot contain. Some Nigerians who were disengaged from their jobs, jilted by their spouse, and abandoned, committed suicide. 


\section{Cases of Suicide in Nigeria}

The table below shows some examples of suicide committed by Nigerians

\begin{tabular}{|c|c|c|c|}
\hline $\mathrm{S}$ & Case & Date & Source \\
\hline 1 & $\begin{array}{l}\text { Toju Daibo a fresh } \\
\text { graduate of the } \\
\text { University of Lagos } \\
\text { reportedly plunged } \\
\text { into Lagos lagoon } \\
\text { from the Third } \\
\text { Mainland Bridge }\end{array}$ & $\begin{array}{l}22 \text { February } \\
2020\end{array}$ & $\begin{array}{l}\text { https://punchng.com/t } \\
\text { hird-mainland-bridge- } \\
\text { nigerias-longest- } \\
\text { flyover-where-suicide- } \\
\text { is-cheap/ }\end{array}$ \\
\hline 2 & $\begin{array}{l}\text { John Ogili } \\
\text { committed suicide } \\
\text { at Umu Ogilieze, } \\
\text { Enugu Ezike in } \\
\text { Igbo-Eze North } \\
\text { Local Government } \\
\text { Area of Enugu State }\end{array}$ & $\begin{array}{l}10 \text { February } \\
2020\end{array}$ & $\begin{array}{l}\text { https://www.vanguard } \\
\text { ngr.com/2020/02/octo } \\
\text { genarian-commits- } \\
\text { suicide-in-enugu-over- } \\
\text { family-denials/ }\end{array}$ \\
\hline 3 & $\begin{array}{l}\text { Inspector Okon } \\
\text { Essien committed } \\
\text { suicide after been } \\
\text { detained in State } \\
\text { CID cell Yaba for } \\
\text { allegedly shooting } \\
\text { and killing one } \\
\text { Hassan Usman }\end{array}$ & $\begin{array}{l}5 \quad \text { February } \\
2020\end{array}$ & $\begin{array}{l}\text { https://www.tvcnews.t } \\
\text { v/police-inspector- } \\
\text { facing-murder-charge- } \\
\text { dies-by-suicide/ }\end{array}$ \\
\hline 4 & $\begin{array}{l}\text { Tope Akinde } \\
\text { committed suicide } \\
\text { in the Opebi area of } \\
\text { Lagos. }\end{array}$ & $\begin{array}{l}1 \text { February } \\
2020\end{array}$ & $\begin{array}{l}\text { https://www.ripplesnig } \\
\text { eria.com/lastma- } \\
\text { official-commits- } \\
\text { suicide-in-lagos/ } \\
\end{array}$ \\
\hline
\end{tabular}




\begin{tabular}{|c|c|c|c|}
\hline 5 & $\begin{array}{l}\text { Maxwell Lucky } \\
\text { Enudi from the } \\
\text { Department of } \\
\text { Zoology, } \\
\text { University of } \\
\text { Calabar committed } \\
\text { suicide after taking } \\
\text { an insecticide } \\
\text { known as "Sniper". }\end{array}$ & $\begin{array}{l}23 \text { January } \\
2020\end{array}$ & $\begin{array}{l}\text { https://www.vanguard } \\
\text { ngr.com/2020/01/fresh } \\
\text {-graduate-commits- } \\
\text { suicide-in-calabar/ }\end{array}$ \\
\hline 6 & $\begin{array}{lr}\text { Miss } & \text { Bolufemi } \\
\text { Motunrayo, a Batch } \\
\text { C youth corps } \\
\text { member serving in } \\
\text { Girls } & \text { Secondary } \\
\text { School, Ibagwa- } \\
\text { Aka committed } \\
\text { suicide }\end{array}$ & $\begin{array}{l}10 \text { January } \\
2020\end{array}$ & $\begin{array}{l}\text { https://www.pulse.ng/ } \\
\text { news/metro/police- } \\
\text { confirms-nysc- } \\
\text { member-bolufemi- } \\
\text { motunrayos-suicide- } \\
\text { in-enugu/0v5z9g8 }\end{array}$ \\
\hline 7 & $\begin{array}{l}\text { Achor Clinton } \\
\text { Chris committed } \\
\text { suicide inside his } \\
\text { apartment in } \\
\text { Rumuekini } \\
\text { community, Obio- } \\
\text { Akpor } \text { Local } \\
\text { Government Area } \\
\text { of Rivers State. }\end{array}$ & $\begin{array}{l}28 \text { December } \\
2019\end{array}$ & $\begin{array}{l}\text { https://dailypost.ng/20 } \\
\text { 19/12/28/man- } \\
\text { commits-suicide-in- } \\
\text { rivers-photo/ }\end{array}$ \\
\hline
\end{tabular}




\begin{tabular}{|c|c|c|c|}
\hline 8 & $\begin{array}{l}\text { Onyechere } \\
\text { Ibeakanma } \\
\text { committed suicide } \\
\text { in his room in } \\
\text { Victoria Island, } \\
\text { Lagos, Nigeria. }\end{array}$ & $\begin{array}{ll}9 & \text { August } \\
2019 & \end{array}$ & $\begin{array}{l}\text { https://www.thenigeria } \\
\text { nvoice.com/news/280 } \\
\text { 688/bank-manager- } \\
\text { commits-suicide-in- } \\
\text { his-victoria-island- } \\
\text { lagos-h.html }\end{array}$ \\
\hline 9 & $\begin{array}{l}\text { Gbenga committed } \\
\text { suicide at Ikare- } \\
\text { Akoko in Akoko } \\
\text { North-East Local } \\
\text { Government Area } \\
\text { of Ondo State }\end{array}$ & 2 May 2019 & $\begin{array}{l}\text { https://dailypost.ng/20 } \\
\text { 19/05/05/young-man- } \\
\text { commits-suicide- } \\
\text { beating-mother-death- } \\
\text { ondo/ }\end{array}$ \\
\hline 10 & $\begin{array}{l}\text { University of } \\
\text { Ibadan lecturer took } \\
\text { his life after an } \\
\text { unfulfilled dream of } \\
\text { completing his PhD } \\
\text { programme }\end{array}$ & 6 April 2019 & $\begin{array}{l}\text { https://www.premiumt } \\
\text { imesng.com/health/he } \\
\text { alth-features/341169- } \\
\text { suicide-and-the-rising- } \\
\text { agony-of- } \\
\text { nigerians.html }\end{array}$ \\
\hline
\end{tabular}

\section{Impact of Suicide in Nigeria}

The impact of suicide on the individuals, their families and the Nigerian society cannot be underestimated. They include:

\section{Short-term Consequences}

The vanguard of suicide gets a bad image after this act. It is believed that the person who commits suicide is a bad person and also not qualified to be given a good burial. One of the family members may even commit suicide to show his or her solidarity with the suicide vanguard. This is because there is a frequent feeling that family members could or should have done something to prevent it, and guilt is very common (Yasgur 2018). People 
bereaved by suicide committed by their relatives are also at increased risk of suicide, depression and psychiatric admission (Spillane, Larkin, Corcoran, Matvienko-Sikar \& Arensman 2017). Parents feel ashamed with regard to the support which they would have given to their children to prevent the suicide.

\section{Long-term Consequences}

The long-term effects of suicide on the dead and their love ones cannot be overemphasised. The family members feel so sad and like if the world has come to an end. The children of the man suffer more than what they were suffering before the man committed suicide. The wife also is maltreated by the in-laws and she suffers to take care of her children. The contribution which the person who committed suicide would have made is lost. Thus, there is the probability of eventual brain drain in Nigeria. The physical presence of the person will be missed by the family, peers, friends, classmates, church members and also co-workers.

Suicide leaves the family of the victim to feel isolated, as if they are facing the tragedy alone. Furthermore, people who knew of the struggle the person that committed the suicide will feel remorse as if they failed to do what they should have done to prevent the suicide. It is sad to note that suicide rate in Nigeria has continued to rise. This is due to the increased frustrations, poverty, depression and hopelessness that Nigerians especially the youths battle with on a day-to-day basis.

\section{Samuel 17:1-23 in the Nigerian Context}

The first theme observable in the pericope is that things worked out well a priori for Ahithophel. He was highly favoured by Absalom. 
In fact, David and Absalom consider the advice of Ahithophel as an oracle from God (2 Samuel 16:23). This tells of how well things worked for him. For his wisdom, he was made the Kings' counsellor (1 Chronicles 27:33). Investigations had revealed that most Nigerians who committed suicide had things working for them in the beginning. They enjoyed certain privileges, comfort, and benefits. Once they loosed this position of theirs, life seems useless and they prefer to take their life than to bear demotion or rejection. Nigerians should realise that life sometimes may be good to them and sometimes things may change for worse. This is where patience and perseverance are needed.

The second theme in the pericope is frustration. Frustration is a state of being annoyed due to one's failure to achieve something(s). Ahithophel had always gotten things done his way. His advice faced no opposition beginning in chapter 16. However, when his advice was thwarted by Hushai, he became frustrated. He waited patiently so see if things might change (vv.25-23), but things continue to grow worse. At this point Hushai had got the approval of the king, which Black \& Rowley (1976:335) reiterate that it was due to the fact that God controls history. The frustration Ahithophel encountered is similar to the Nigerian environment, where frustrations are everywhere (Onyegbula 2019). Individuals set goals and objectives. They set personal goals, family goals, educational goals, economic goals, and marital goals. When their goals cannot materialize, they become sad and annoyed, seeing nothing good in life anymore. For instance, Agbedo (2019) wrote that there is no hope for youths now and in future in Nigeria that is why frustration sets in. This is the reason some Nigerians have lost hope that things will be okay, hence, they resolve taking their life as an escape mechanism. Nigerians should not allow frustration 
becloud their sense of reasoning. They should seek conselling from psychologists or trusted friends.

The third theme is bitterness in the soul. Ahithophel allowed this sadness and failure to becloud his sense of reasoning. From v.5, Ahithophel tried all he could to see his ambition come through. He waited patiently (v.22) until he discovered that all hope was lost. There was no remedy to his plight. He could not bear the shame of what people around would say. Nobody was there to comfort him. The family did not know what he was going through (v.23). Instead, we are told that he puts his family in order before taking his life. Had it been the family members were more observant, they would have questioned the "putting house in order" static that their father and husband carried out. Nobody understood or help Ahithophel overcome the bitterness in his soul. This is evident in the Nigerian context, where people that committed suicide usually gives a signal to friends and relatives which only the wise ones can decode. For instance, Akachi who killed himself on 12 May 2019 posted the following on Facebook on the same day: "My mental health has been on life support for a while now. Thanks to those who call. Text. Visit. Speak to me. May we always remember. May we never forget. You may have added a few hours, months or days to my time here. But you know life support is expensive right? Thank you for trying. Amen" (Ikem 2019). They may say it verbatim, they may show it in their mood, they may show it in their melancholic nature; they may show it in their feeling of defeat and anguish. So many Nigerians are working corpse; they have died a billion times mentally. A physical manifestation is what they plan to achieve through suicide. In fact, 
suicide has taken the lead against HIV/AIDS and malaria in Nigeria.

The fourth theme concerns how suicide is used as a conflict resolution strategy. Ahithophel discovered that all hope was lost. Having waited patiently for a change of situation, and the status quo remained, he decided to hang himself in the house when he was alone (v.23). But before he did that, he arranged the property in his house, in anticipation that he will be no more. Ahithophel realized as his plan failed, that David would be restored to his throne, and he will be condemned for his disloyalty to David and would face the death penalty; therefore, he chose to end his own life rather than be put to death by others (Hale 2007:595). This indicator is seen in most suicide cases and scenes in Nigeria. First, the victim of suicide writes a note stating that how life has been unfavourable over a period. This is a way of keeping his/her house in order. Second, the victim of suicide commits this act in a lonely place. They do not want anybody to see them. They feel that they are not qualified to be part of the world anymore. Some Nigerians hang themselves; others drink pesticides, insecticides, dettol; while others set themselves on fire.

Suicide has continued to rise to the failure of the government to put in place intervention programmes to prevent or reduce the trend. The relevance of the pericope to the Nigerian context cannot be overemphasised. I believed that drawing the themes to shed light on the phenomenon of suicide in the Nigerian context is justified by the tendency for continuous rereading, interpretation and reinterpretation of the scriptures.

\section{What Can be Done about the Problem of Suicide in Nigeria}

The following suggestions may help to ameliorate the problem of suicide in Nigeria: 
1. Ahithophel committed suicide because things he expected to work out for him failed to. Nigerians should not expect things to always work well for them. Sometimes, when things work against their expectation. They should endure and seek a better survival strategy.

2. Ahithophel saw the loss of his influence on the rulers and elders of Israel as a clear signal of a lost future. Nigerians should not regard themselves as being a rejected human being when they lose an opportunity, a friend, a grade, a lover or an employment opportunity. With perseverance and hope, things may turn out well for them.

3. Ahithophel committed suicide because he failed to share his problems with his family members. Nigerians passing through frustration, pains, psychological injury and rejection should try to share their problems with others. This was what Ahithophel failed to do. Instead of taking one's own life, problems and challenges should be shared with friends, family members, mentors and also close associates.

4. Ahithophel suicide brought shame on himself and his family. Suicide is not an escape mechanism from shame. In one way or the other, a human being must pass through shame. One should be strong enough to know that only the strong survive and the wise excel. A wise person excels after a shameful situation. The news of suicide is more shameful than the situation that the suicidal was passing through before the suicide. Those contemplating on committing suicide should think twice and know that that shameful situation is just temporary. They should be strong 
and hold their face high. The person thinking of committing suicide should avoid listening or thinking what people are feeling or will see him or her, regarding the situation he/she is going through.

5. Those contemplating committing suicide should know that their friends and relatives will pass through excruciating pains upon hearing about the news of their death. They should also know that these close relatives may even commit suicide because of them. So, it is better to think about what gains your living have on friends and relatives than they gain you will get from committing suicide.

6. People who were briefed by those passing through severe situations should help in one way or the other in their quest towards dissuading the person from committing suicide. Instead of taking the complaints, signals, imageries and character that the person attempting to committing suicide postulates with a pinch of salt, people should give a helping hand to those who are nursing the ambition of committing suicide.

\section{Conclusion}

Suicide is a result of frustration caused by poverty, unemployment, peer pressure, family pressure and falling below personal, family and societal expectations. These reoccurring indices have been reoccurring from Old Testament Times to contemporary times. In the pericope, Ahithophel committed suicide by hanging himself from the physical, mental, and emotional challenges he encountered. All of these challenges culminated in frustration. The frustrated, since the time of ancient Israel, are prone to adopting suicide to address their problems and challenges. The suicide committed by Ahithophel did not bring a solution to the frustration 
that he was passing through. Ahithophel thought that committing suicide would take away the shame; instead, it made the shame not only for him but for everyone. Everyone saw that the triumph of David, which he tried to avert by killing himself, came to pass. Nigerians thinking of committing suicide because of their situation should have another rethinking. The poverty, suffering, frustration and anguish in Nigeria should not be seen as a reason any Nigerian to take his/her life. It is better to stay alive and fight for a better day with patience, hope and endurance, than taking the step of a coward through suicide.

\section{Favour C. Uroko}

Department of Religion and Cultural Studies, University of Nigeria, Nsukka. Favour.uroko@unn.edu.ng

\section{Solomon Enobong}

Department of Religion and Cultural Studies, University of Nigeria, Nsukka. Enoenosol1@ gmail.com 


\section{References}

Adesoji, B.O., 2020, 'Over 82 million Nigerians are poor, northern states dominate list', viewed 3 July 2020, from https://nairametrics.com/2020/05/04/breaking-over-82million-nigerians-are-poor-northern-states-dominate-list/ Adewuya, A.O., \& Oladipo, E.O., 2019, 'Prevalence and associated factors for suicidal behaviours (ideation, planning, and attempt) among high school adolescents in Lagos, Nigeria', European Child \& Adolescent Psychiatry, $1-10$.

Agbedo, O., 2019, 'Real reasons Nigerian youths are committing suicide', viewed Guardian, May 25, p.1.

Akanni, G., \& Weanzana, N., 2006, '1 \& 2 Samuel', African Bible

Commentary, Tokunboh Adeyomo ed., WordAlive Publishers, Nairobi, Kenya.

Barton, J., \& Muddiman, J., 2002, The Oxford Bible Commentary, Oxford University Press, Oxford.

Black, M., \& Rowley, H.H., 1976, Ed. Peake's Commentary on the Bible, Thomas Nelson and Sons, Ikeja.

Bodner, K., 2002, 'Motives for defection: Ahithophel's agenda in 2 Samuel 15-17', Studies in Religion/Sciences Religieuses, 31(1), 63-78.

Campbell, A.F., \& Flanagan, J.W., 2018, '1-2 Samuel', Raymond E. Brown, Joseph A. Fitzmyer, Roland E. Murphy, ed.The New Jerome Biblical Commentary, Theological Publications, Bangalore.

Chafin, K.L., 2004, '1 and 2 Samuel', The Preacher's Commentary,Vol.08, Thomas Nelson, Nashville, Tennessee Child, I.L., \& Waterhouse, I.K., 1953, 'Frustration and the quality of performance: II. A theoretical statement', Psychological Review, 60(2), 127. 
Dayo, J., 2020, 'Policeman kills wife, self over alleged infidelity in Ondo', Vanguard, 11 March, p.1.

Desmond, A.T., \& Rosner, B.S., 2000, New Dictionary of Biblical Theology, InterVarsity Press, Illinois.

Fokkelman, J.P., 1981, 'David's Escape: How Hushai wins and Ahithophel Loses', European Judaism, 15(1), 44.

Gordon, R.P., 1998, I \& II Samuel: A Commentary, Zondervan Publishing house, Grand Rapids, Michigan.

Gray, J.M., 1999, The Concise Bible Commentary,

1999, Peabody, Massachusetts, Hendrickson Publishers

Hale, T., 2007, The applied Old Testament Commentary, David C. Cook, Canada.

Hastings, J., Selbie, J.A., Lambert, J.C., \& Mathews, S., 1930, Dictionary of the Bible, Charles Scribner's sons, New York. Heater, H., 1991, 'A theology of Samuel and Kings', A Biblical Theology of the Old Testament, Ed. Roy B. Zuck, Moody Press, Chicago.

Hertzberg, H. W., 1964, '1 and 2 Samuel: A Commentary', tr. J. S.Bowden, Old Testament Literature, SCM, London.

Hertzberg, H.W., 1965, I and II Samuel: a Commentary, Westminster Press, Philadephia.

Iemmi, V., Bantjes, J., Coast, E., Channer, K., Leone, T., McDaid, D., Palfreyman, A., Stephens, B. and Lund, C., 2016, 'Suicide and poverty in low-income and middle-income countries: a systematic review', The Lancet Psychiatry, 3(8), 774.

Ikem, F., 2019, '400-level UNN student commits suicide, leaves poetic note', TheSun, Voice of the Nation, 14th May, p.1 
Keil, C.F., \& Delitzsch, F., 2014, Commentary on the Old Testament, Titus Books, Auckland, New Zealand.

Kohlenberger, J.R., 1987, The Interlinear NIV Hebrew-English Old

Testament, Zondervan Publishing House, Grand Rapids.

Long, V.P., 1993, 'First and second Samuel', in L. Ryken \& T.

Longman (eds.), A complete literary guide to the bible, Zondervan, Grand Rapids, MI.

Mac-Leva, F., Ibrahim, H., \& Usman, U.S., 2019, 'Students top list as 42 Nigerians commit suicide in 6 months', DailyTrust, 2 June, p. 1

Margolin, U., 1990, 'The what, the when, and the how of being a character in literary narrative', Style, 24(3), 453.

McCarter, P. K., 1980, 1 Samuel, Doubleday, Garden City, NY.

Muanya, C., Akpunonu, S., \& Onyenucheya, A., 2019, 'Addressing rising cases of suicide among teenagers in Nigeria', TheGuardian, 21 May, p.1.

Odenyi, S. (2021). "Man commits suicide after losing company's N150,000 on betting", ThePunch, 8 December.

Onyegbula, E., 2019, 'Suicide craze: Fear, rejection, frustration, other reasons children, students, young adults take own lives', Vanguard, 26 May, p.1.

Oyetunji, T. P., Arafat, S. Y., Famori, S. O., Akinboyewa, T. B., Afolami, M., Ajayi, M. F., \& Kar, S. K. (2021). Suicide in Nigeria: observations from the content analysis of newspapers. General psychiatry, 34(1).

Plutchik, R., Van Praag, H.M., Conte, H.R. \& Picard, S., 1989, 'Correlates of suicide and violence risk 1: the suicide risk measure', Comprehensive psychiatry, 30 (4), 296. 
Scherr, S., \& Reinemann, C., 2011, 'Belief in a Werther Effect: Third-Person Effects in the Perceptions of Suicide Risk for Others and the Moderating Role of Depression', Suicide and Life-Threatening Behavior, 41(6),624.

Spillane, A., Larkin, C., Corcoran, P., Matvienko-Sikar, K. \& Arensman, E., 2017, 'What are the physical and psychological health effects of suicide bereavement on family members? Protocol for an observational and interview mixed-methods study in Ireland', British Medical Journal open, 7(3):1.

Stengel, E., 1964, Suicide and attempted suicide, Penguin Books, London.

Tsevat, M. 1958, 'Marriage and Monarchical Legitimacy in Ugarit and Israel', Journal of Semitic Studies, (3): 237.

Yasgur, B. S., 2018, 'Those Left Behind: Working With SuicideBereaved Families', viewed October 4, 2018, from https://www.psychiatryadvisor.com/ home/topics/suicideand-self-harm/those-left-behind-working-with-suicidebereaved-families/

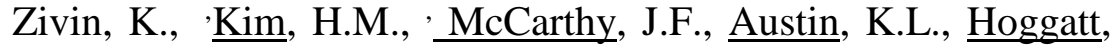
K.J., Heather Walters, H., \& Valenstein, M., 2007, 'Suicide Mortality Among Individuals Receiving Treatment for Depression in the Veterans Affairs Health System: Associations with Patient and Treatment Setting Characteristics', American Journal of Public Health 97(12), 2193. 